SVETLA STOILOVA, Ph.D.

E-mail: stoilova@tu-sofia.bg

Technical University of Sofia, Faculty of Transport

8 Kl. Ohridski Blvd., 1000, Sofia, Bulgaria
Transport Planning

Preliminary Communication

Submitted: 11 Feb. 2019

Accepted: 26 Sep. 2019

\title{
A MULTI-CRITERIA ASSESSMENT APPROACH FOR THE EVALUATION OF RAILWAY TRANSPORT IN THE BALKAN REGION
}

\begin{abstract}
The Balkan region has an important geostrategic position in passenger and freight transport between Europe and Asia. This paper studies the development of railway transport on twelve different railway transport markets in the Balkan region. The methodology is based on multi-criteria assessment of the level of railway development. The approach presented in this paper could help railway companies to make decisions about railway transport services. The methodology includes three steps. In the first step, the quantitative and qualitative criteria for the evaluation of the social, economic, infrastructural and technological impact of the level of development of railway transport have been defined. In the second step, the weights of criteria have been determined using both objective and subjective approaches by applying the Shannon Entropy method and the Stepwise Weight Assessment Ratio Analysis (SWARA) method. The third step presents the ranking of the countries by applying three multi-criteria methods - VIse Kriterijumska Optimizacija i kompromisno Resenje (VIKOR), Weighted Aggregated Sum Product Assessment (WASPAS) and Preference Rank ing Organization Method for Enrichment Evaluation (PRO METHEE), which are different in their approaches. The results show that the criteria: maximum train technical speed (13\%), ERTMS Level (10\%), number of train kilometres per year (9\%) and Ro-La intermodal service (9\%) have a great importance in the ranking. It was found that the most developed railway transports in the Balkan region are Turkey, Croatia, Slovenia, and Romania.
\end{abstract}

\section{KEY WORDS}

railway transport; entropy; evaluation;

\section{INTRODUCTION}

There are twelve countries lying in the Balkan region and they have an important role in the transport links between Europe and Asia. The countries whose whole territory is on the Balkans are: Albania, Bosnia and Herzegovina, Bulgaria, Greece, Kosovo (this designation is without prejudice to positions on the status, and in line with UNSCR 1244/1999 and the ICJ Opinion on the Kosovo declaration of independence), North Macedonia and Montenegro. Most of the territory of
Serbia, Croatia and Slovenia is in the Balkans, too. Romania and Turkey have a small part of their territory on the Balkan peninsula.

Four transport corridors from the Trans-European Transport Core Network (TEN-T) run across the Balkan region: the Orient/East-Med passes through the territory of Bulgaria, Romania and Greece; the Baltic - Adriatic passes through the territory of Slovenia; the Rhine - Danube passes through the territory of Bulgaria and Romania; the Mediterranean passes through the territory of Croatia and Slovenia.

The European Union funded the transport projects on the Balkans for railway transport to extend the core network. Railway transport is ecological and therefore its development is important for the environmental protection. Due to the traffic-geographical position the countries in the Balkan region are included in the European global and regional traffic courses in linking the Central European space with Asia.

The hypothesis of the study is that the railway transport in the Balkan region has different levels of development and that it can be ranked according to the complex impact of criteria related to the transportation, infrastructure and social activities by applying multi-criteria analysis. The assessment of railway transport in the Balkan region and its ranking is an important tool for comparing the level of its development and could help the railway companies in making decisions about the extension and improvement of the railway transport services.

The aim of the study is to examine the railway transport on twelve different railway transport markets in the Balkan region by ranking them according to the criteria related to their development. The level of railway transport in these countries impacts the economic development, transport mobility and connectivity in the individual states and Europe as a whole.

The methodology of the study includes: defining the criteria to assess railway transport; determining the weights of the criteria by applying a combination of objective and subjective approaches; ranking the 
studied countries by using different in nature multi-criteria methods VIKOR, WASPAS and PROMETHEE; verification of results.

The structure of the paper is as follows: Section 2 presents a literature review; Section 3 constructs a research methodology; Section 4 presents the computational procedures and an analysis of the results. Finally, Section 5 draws the conclusion.

\section{LITERATURE REVIEW}

The Balkan region has been studied in terms of its economic development, transport, ecology, logistics, tourism performance, global competitiveness and other characteristics.

In [1] the Balkan region has been studied for the impact of sustainable competition in the region using twelve factors of the World Economic Forum. The authors have grouped the studied factors into three sub-indices as the basic requirements: efficiency enhancers, innovation and sophistication criteria. To classify the Balkan countries the k-means Cluster analysis was applied and two clusters were formed. The first includes: Bulgaria, Croatia, Greece, Romania, Serbia, and Turkey. The second cluster comprises Albania, Bosnia and Herzegovina, Macedonia, Montenegro, and Slovenia.

In [2] the econometric methodology was used to explore the issue of income convergence of the Balkan economies with the European Union - 15 average (EU15) over the period from 1989 to 2009. It was found that there is a positive average slope only for Greece and Slovenia.

In [3] the Pan-European Transport Axes on the Balkans, in terms of two characteristics: population and land access, were investigated. The Cluster Analysis method was used to study the systematic exploration of the impact of the Pan-European Transport Axes on 35 cities of the Balkan area. According to the study, three geographical units were formed.

The level of ERTMS deployment in Western Balkans was studied in $[4,5]$. Six countries (Albania, Bosnia and Herzegovina, North Macedonia, Serbia, Montenegro and Kosovo) have been assessed by ERTMS status for all three pillars of successful ERTMS (European Railway Traffic Management System) implementation - legislative, strategic and implementation. The authors found that North Macedonia and Montenegro are ahead compared to other investigated countries.

In [6] the level of logistic competition of the Balkan countries was studied by applying multi-criteria evaluation. The authors evaluated and compared ten countries on the Balkan Peninsula (Albania, Bosnia and Herzegovina, Bulgaria, Montenegro, Croatia, Greece, Macedonia, Romania, Slovenia, and Serbia) using the PROMETHEE method. The 20 evaluation criteria forming the basis for the supply chain logistic evaluation were introduced. It was found that Croatia emerged as a country which offers the most suitable logistic conditions; followed on the second and third place by Slovenia and Montenegro.

In [7] eleven Balkan countries (Albania, Bosnia and Herzegovina, Bulgaria, Croatia, Greece, Macedonia, Montenegro, Romania, Serbia, Slovenia, and Turkey) were examined for their tourism performance. The regression analysis was used. It was established that air transport infrastructure, health and hygiene, safety and security, and human resource variables affected tourism performance of the Balkan countries.

In [8] a research of the global competitiveness of six countries of the Western Balkans (Croatia, Bosnia and Herzegovina, Serbia, Montenegro, Albania and Macedonia) for the period from 2006 to 2014 was made. It used the Global Competitiveness Index of the World Economic Forum including 12 indicators to investigate the countries. It was found that Croatia and Montenegro showed the best scores for the criterion of competitiveness. In terms of the infrastructure development criterion Croatia had the best score.

Three Balkan countries, Slovenia, Romania and Bulgaria, were included in the research in [9] with a total number of 22 countries in the study of railway transport in Europe. The European Performance Index (EPI) was chosen as a measure of the performance of railway systems for both passenger and freight transport by intensity of use, quality of service and safety. The results of this research show that Slovenia holds the 18th place, Romania the $24^{\text {th }}$ place and Bulgaria occupies the last, $25^{\text {th }}$ place.

In [10] an analysis of the development of the factor of productivity in the European railways using data from 22 European countries for the years from 1990 to 2005 is presented. Two Balkan countries have been included in this analysis. The level of technical efficiency score was found to be $70.2 \%$ for Greece and $73.6 \%$ for Slovenia.

The World Bank made research of the Logistic Performance Index (LPI) and ranked the countries on six dimensions of the movement of goods including customs performance, infrastructure quality, and timeliness of shipments, [11]. The scores of the six components indicate the country logistics performance index for 167 countries from all over the world. This research included eleven Balkan countries with the exception of Kosovo. LPI refers to the carriage of goods and includes different modes of transportation. According to this research the prioritization of the Balkan countries is as follows: Turkey (37), Slovenia (39), Greece (44), Croatia (48), Romania (50), Bulgaria (57), Serbia (68), Bosnia and Hercegovina (78), Albania (98), Montenegro (94), Macedonia (99); the country rank is given in brackets. 
In this study three different multi-criteria methods are proposed: VIKOR, PROMETHEE and WASPAS to assess the railway transport. Comprehensive reviews of the use of the VIKOR method could be found in [12]; and of the use of the PROMETHEE method in [13]. The VICOR method is employed for transport research of the railway route selection, and the assessment of infrastructure design projects, [14]; the selection of the forklift unit for warehouse operation, [15]; in maritime transportation industry, [16]; for evaluation of infrastructure railway project, [17]. The WASPAS method is used for the evaluation of potential locations for roundabout construction, [18]; the examples of different applications, [19].

\section{RESEARCH METHODOLOGY}

In the study, the railway markets as a whole, of both passenger and freight transport were studied. The methodology includes three steps, Figure 1.
In the first step, the criteria for the evaluation of the railway transport are determined. The values of the criteria for the studied countries are determined through data from the Eurostat and UIC for the period from 2012 to 2017.

In the second step, the weights of the criteria are determined using the objective and subjective approaches: the Shannon Entropy method and the Stepwise Weight Assessment Ratio Analysis (SWARA) method. In the third step the results obtained for the weights of the criteria are applied to rank the countries. Three multi-criteria methods are used for the ranking: VIKOR, WASPAS and PROMETHEE. These methods make use of different approaches for the ranking of the alternatives. The VIKOR method is distance-based and classifies alternatives and defines the solution, called the compromise that is closest to the ideal. The WASPAS method uses a weighted approach. Both methods use parameters with values from 0 to 1 that permit the study of the sensitivity of the solution. The PROMETHEE method has

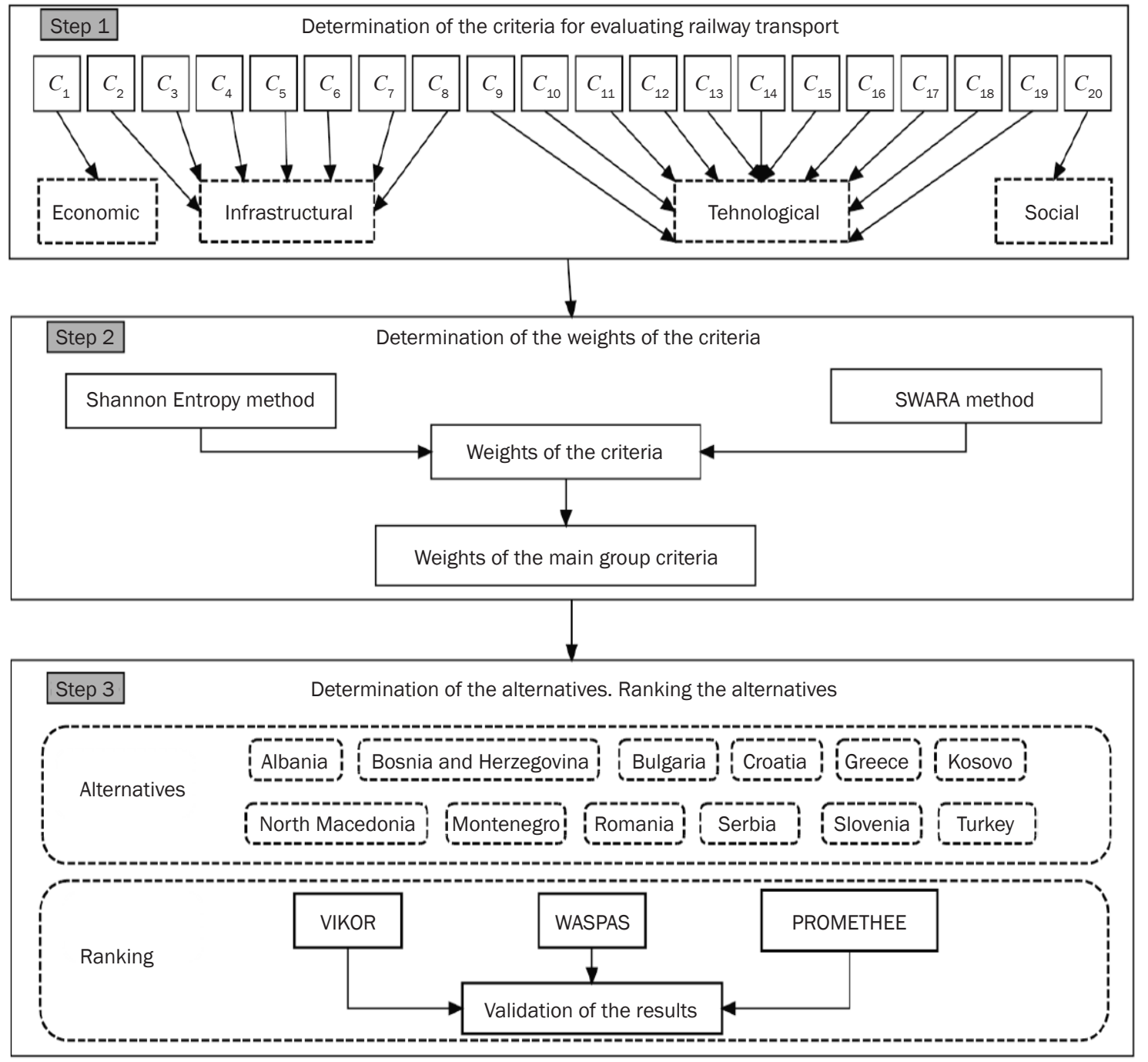

Figure 1 - Scheme of the methodology 
an outranking nature. The ranking using three different approaches makes it possible to verify the results and explore their consistency and robustness.

\subsection{Step 1: Determination of the criteria for evaluating railway transport}

The evaluation of railway transport is made according to the following quantitative and qualitative criteria showing the social, economic, infrastructural and technological impact of the level of development. Table 1 presents the criteria for the assessment of the railway transport.

The criteria: availability of Ro-La service $\left(C_{5}\right)$, maximum train technical speed $\left(C_{6}\right)$, ERTMS Levels $\left(C_{7}\right)$ and the availability of car shuttle service $\left(C_{20}\right)$ are qualitative criteria and the others are quantitative ones.

\subsection{Step 2: Determination of the weights of the criteria}

The process of defining the weights of the criteria is important for the ranking of the alternatives. There are different methods of determining the weights of the criteria; some are objective, such as Shannon Entropy, which is based on the information obtained from data, and others are subjective such as AHP, DEMATEL as they use experts and assessment scales.

This study uses an objective and a subjective approach as two divergent ways of determining the weights of the criteria. The Shannon Entropy method

Table 1 - Criteria for the assessment of the railway transport

\begin{tabular}{|c|c|c|}
\hline \multicolumn{2}{|c|}{ Criterion } & \multirow{2}{*}{ Description } \\
\hline Type & Name & \\
\hline Economic & $C_{1}$ & $\begin{array}{l}\text { Gross domestic product per capita, [thousands \$]. This criterion presents the level of the } \\
\text { economic development of the countries. }\end{array}$ \\
\hline \multirow{6}{*}{ 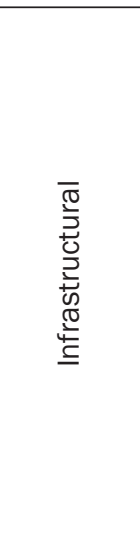 } & $C_{2}$ & Length of the railway network, $[\mathrm{km}]$. This indicator presents the scope of rail transport in the country. \\
\hline & $C_{3}$ & $\begin{array}{l}\text { Density of the railway network, [thousands } \mathrm{km} / \mathrm{km}^{2} \text { ]. This criterion is a measure of the degree of } \\
\text { development of railway transport. }\end{array}$ \\
\hline & $C_{4}$ & $\begin{array}{l}\text { Coefficient of electrified railways lines. This criterion shows the level of the development of } \\
\text { railway transport represented by the length of electrified railway lines divided by the total length of the } \\
\text { railways. }\end{array}$ \\
\hline & $C_{5}$ & $\begin{array}{l}\text { The availability of Ro-La service. Ro-La trains are intermodal transportation of heavy goods vehicles } \\
\text { with specialized wagons. This technology requires the availability of specialized intermodal terminals, } \\
\text { which is an indicator of the development of transport infrastructure. This indicator can take values of } \\
0 \text { or 1. } C_{5}=1 \text { if the country has Ro-La trains. } C_{5}=0 \text {, otherwise. }\end{array}$ \\
\hline & $C_{6}$ & $\begin{array}{l}\text { Maximum train technical speed. This indicator can take values of } 0,1 \text { or } 2 . C_{6}=2 \text { if the maximum train } \\
\text { technical speeds are over } 200 \mathrm{~km} / \mathrm{h} ; C_{6}=1 \text { medium (or higher) speeds over } 160 \mathrm{~km} / \mathrm{h} ; C_{6}=0 \text { if the } \\
\text { conventional [-] speeds are below } 160 \mathrm{~km} / \mathrm{h} \text {. }\end{array}$ \\
\hline & $C_{7}$ & $\begin{array}{l}\text { ERTMS Levels. This indicator can take values of } 0,1 \text { or } 2 . C_{7}=2 \text { if the country has Level } 2 \text { of ERTMS; } \\
C_{7}=1 \text { if the country has Level } 2 \text { of ERTMS, } C_{7}=0 \text { otherwise. }\end{array}$ \\
\hline \multirow{12}{*}{ 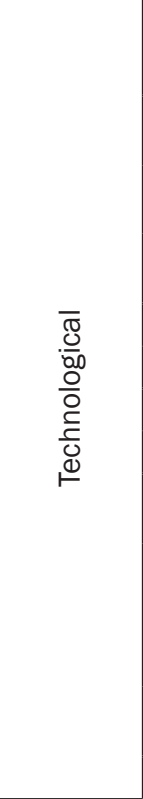 } & $C_{8}$ & $\begin{array}{l}\text { The number of train-kilometres per year, [million train. } \mathrm{km} / \text { year]. Train-kilometres represents the } \\
\text { distance actually covered by a train. It is an indication of how the rail network is being used. }\end{array}$ \\
\hline & $C_{9}$ & $\begin{array}{l}\text { Network usage intensity, [million train. } \mathrm{km} / \mathrm{km} \text { ]. This criterion represents the average number of } \\
\text { trains per route kilometre per day. This shows the intensity with which the rail network is being used. }\end{array}$ \\
\hline & $C_{10}$ & $\begin{array}{l}\text { Number of passengers per year, [million pass. / year]. The number of carried passengers shows the } \\
\text { preferences of passengers to the respective mode of transport. }\end{array}$ \\
\hline & $C_{11}$ & $\begin{array}{l}\text { Number of passenger-kilometres per year, [millions pass.km / year]. This indicator shows the level of } \\
\text { utilisation of railway transport by passengers. }\end{array}$ \\
\hline & $C_{12}$ & Intensity of usage of railway network by passengers, [million pass.km / km]. \\
\hline & $C_{13}$ & Intensity of utilisation of railway passenger transport per capita, [pass.km per capita]. \\
\hline & $C_{14}$ & Intensity of use of rail transport by the population, [passengers per capita] \\
\hline & $C_{15}$ & Level of utilisation of railway network by passengers,[thousands pass. / km]. \\
\hline & $C_{16}$ & $\begin{array}{l}\text { Number of tons carried per year, [million tons/year]. It shows the preferences of customers to use } \\
\text { railway transport. }\end{array}$ \\
\hline & $C_{17}$ & $\begin{array}{l}\text { Number of reduced ton-kilometres, [million ton.km / year]. This indicator stands for the level of } \\
\text { utilisation of railway transport. It is determined as the sum of net ton-kilometres and } \\
\text { transformed passenger-kilometres. The passenger-kilometres are transformed by using a coefficient } \\
\text { equal to } 0.66 \text {. }\end{array}$ \\
\hline & $C_{18}$ & $\begin{array}{l}\text { Intensity of usage of railway network, [million ton. } \mathrm{km} / \mathrm{km} \text { ]. This criterion represents the number of } \\
\text { reduced ton-kilometres per route kilometre per day. }\end{array}$ \\
\hline & $C_{19}$ & The level of utilisation of railway network by freight transportation, [thousands tons / km]. \\
\hline Social & $C_{20}$ & $\begin{array}{l}\text { The availability of car shuttle service. Car shuttle trains offer a service by which passengers can take } \\
\text { their car or automobile along with them on their journey. Cars are transported in specialized wagons. } \\
\text { This indicator can take values of } 0 \text { or } 1 . C_{20}=1 \text { if the country has car shuttle trains. } C_{20}=0 \text {, otherwise. }\end{array}$ \\
\hline
\end{tabular}


makes it possible to determine the weights of criteria according to the information provided by the data and to use the mathematical formulation to perform the ranking of alternatives. Subjective weighting depends on the decision maker's judgment. The Stepwise Weight Assessment Ratio Analysis (SWARA) is employed as a subjective method, which uses experts to determine the weights of the criteria. This makes it possible to take into account the opinion of the specialists who know the nature of the research problem. Finally, the weights are determined according to these two methods.

The decision matrix $\left(x_{i j}\right)_{m x n}$ is formed according to the data of criteria for the studied alternatives, $i=1, \ldots, n$ is the number of criteria, $j=1, \ldots m$ is the number of alternatives.

\section{Shannon Entropy method}

This concept uses the information entropy to determine the weights of the criteria.

The information entropy for each criterion $C_{i}$ is determined as follows, [20]:

$$
\begin{aligned}
& E_{i}=-\frac{\sum_{i=1}^{n} p_{i j} \ln p_{i j}}{\ln n} \\
& 0 \leq E_{i} \leq 1
\end{aligned}
$$

where: $k$ is a constant; $p_{i j}$ is the normalized values of decision matrix $\left(x_{i j}\right)_{m x n}, i=1, \ldots, n$ number of criteria, $j=1, \ldots m$ is the number of alternatives.

Normalized values $p_{i j}$ are determined as follows:

$$
p_{i j}=\frac{x_{i j}}{\sum_{i=1}^{n} x_{i j}}
$$
lows:

The values of parameter $D_{i}$ are calculated as fol-

$$
D_{i}=1-E_{i}
$$

The weights of criteria are determined using values of parameter $D_{i}$.

$$
w_{i}^{E}=\frac{D_{i}}{\sum_{i=1}^{n} D_{i}}
$$

The following conditions are valid:

$0 \leq w_{i}^{E} \leq 1, \quad \sum_{i=1}^{n} w_{i}^{E}=1$

\section{SWARA method}

The Stepwise Weight Assessment Ratio Analysis Method (SWARA) has been elaborated in [21]. This method has different applications; in transport it has been used for the evaluation and selection of key performance indicators to assess the transportation of goods in road transport, [22]; assessment of the criteria for selecting the model of restructuring and organisation of railway companies, [23]. This method is an easy and powerful tool that uses experts to evaluate the criteria. The method based on experts' assessment of the comparative importance of criteria, and recalculated weights. SWARA does not use a scale for evaluation, as for example in the AHP method and DEMATEL method, which makes this approach convenient for the experts to evaluate the criteria.

The method consists of the following steps:

Step 1: The expert ranks the criteria in descending order of their expected significance.

Step 2: Determination of the comparative importance of average values $S_{i}$ [21]. For this purpose, starting from the second criterion, the expert assesses the relative importance of criterion $j$ to the previous $(j-1)$ criterion.

Step 3: Determination of the value of coefficient $k_{j}$

$k_{j}=1$, if $j=1 ; k_{j}=s_{j}+1$, if $j>1$

Step 4: Determination of the recalculated weight $q_{j}$ :

$q_{j}=1$, if $j=1 ; q_{j}=\frac{q_{j-1}}{k_{j}}$, if $j>1$

Step 5: Calculation of the weight of criteria as follows:

$w_{i}^{S}=\frac{q_{j}}{\sum_{k=1}^{n} q_{j}}$

where: $w_{i}^{S}$ - represents the relative weight of the criteria.

For the weights the following condition must be met:

$0 \leq w_{i}^{S} \leq 1, \sum_{i=1}^{n} w_{i}^{S}=1$

To determine the consistency of the experts' assessment in the study, the Spearman Rank correlation coefficient is proposed, [24].

$r_{s}=1-\frac{6 \cdot \sum_{i=1}^{n} d_{i}^{2}}{n\left(n^{2}-1\right)}$

where: $r_{s}$ is the Spearman Rank correlation coefficient; $d_{i}$ is the distance between the ranks for each $x_{i}, y_{i}$ data pairs; $n$ is the number of elements in each data series (i.e. the number of criteria).

$0 \leq r_{s} \leq 1$

This approach allows us to determine the correlation between the evaluations obtained by experts.

Weights of the criteria

The weights of the criteria are determined by taking into account the results of both methods applied.

$w_{i}=\varepsilon \cdot w_{i}^{E}+(1-\varepsilon) \cdot w_{i}^{S}$

$0 \leq \varepsilon \leq 1$

where: $w_{i}$ are the weights of criteria, $\varepsilon$ is a parameter representing the weights of the used method. 
This approach of combining the weights given by the Shannon Entropy method and the SWARA method make it possible to make use both of information and expert assessment, and permits us to reduce subjectivism when making a decision. The application of these ways of weight assessment permits also performing a sensitivity analysis of the results.

The weights of the main groups criteria are determined by using the weights of pre-determined weights of all criteria as follows:

$$
\begin{aligned}
& w_{g}=\frac{\bar{w} g}{\sum_{g=1}^{G} \bar{w}_{g}} \\
& \bar{w}_{g}=\frac{\sum_{k=1}^{K} w_{g k}}{K}
\end{aligned}
$$

where: $g=1, \ldots ; G$ is the number of the main group criteria; $w_{g}$ is the weight of the main group $g ; \bar{w}_{g}$ is the average weight for the criteria of the main group $g$; $k=1, \ldots, K$ is the number of criteria in the main group $g$.

\subsection{Step 3: Ranking of the alternatives}

In this step, according to the methodology, three methods are applied for ranking the alternatives.

\section{The VIKOR method}

The VIKOR method has been elaborated in [25] and is based on the measure to the ideal solution. This method can be summarised as follows:

Step 1: Determination of the best $f_{i}^{*}$ and the worst $f_{i}$ values of all criterion functions. $f_{i}^{*}$ is calculated when $i$-th criterion represents a benefit; $f_{i}^{-}$is calculated for non-beneficial criteria as follows.

$f_{i}^{*}=\max _{j} f_{i j} ; \quad f_{i}=\min _{j} f_{i j}$

Step 2: Determination of the distance from each alternative to the positive ideal solution.

$S_{j}=\sum_{i=1}^{n} \frac{w_{i}\left(f_{i}^{*}-f_{i j}\right)}{f_{i}^{*}-f_{i}}$

$R_{j}=\max _{j} \frac{w_{i}\left(f_{i}^{*}-f_{i j}\right)}{f_{i}^{*}-f_{i}}$

where: $S_{j}$ - is the distance of $j$-th alternative to the positive ideal solution; $R_{j}$ is the maximal regret of each alternative; $w_{i}$ represents the weights of the criteria. Step 3: Determination of the index value $Q_{j}$

$$
\begin{aligned}
& Q_{j}=\frac{v\left(S_{j}-S^{*}\right)}{S^{-}-S^{*}}+\frac{(1-v)\left(R_{j}-R^{*}\right)}{\left(R^{-}-R^{*}\right)} \\
& S^{*}=\min _{j} S_{j} ; S^{-}=\max _{j} S_{j} \\
& R^{*}=\min _{j} R_{j} ; \quad R^{-}=\max _{j} R_{j}
\end{aligned}
$$

where: $v$ is the weight of the decision-making strategy, representing the optimism level of the decision maker.

The following condition is valid:
$0 \leq v \leq 1$

When $v=1$, it represents the choice of a strategy with maximum group utility; when $v=0$, it means a strategy of minimum individual regret. Value $v=0.5$ is usually selected.

The best alternative is the one with the minimum value of index $Q_{j}$.

Step 4: Examination of the stability of the optimal result. Alternative $A^{(1)}$ which is the best ranked by the minimum of index $Q_{j}$ has to satisfy two conditions.

The first condition is checked for acceptable advantage:

$Q\left(A^{(2)}\right)-Q\left(A^{(1)}\right) \geq \frac{1}{m-1}$

where $A^{(2)}$ is the alternative with the second position in the ranking list by $Q$.

The second condition is checked for acceptable stability in decision making. This means that alternative $A^{(1)}$ is the best ranked also by parameters $S$ or/and $R$ for all values of $v$.

If one of both conditions is not satisfied, then a set of compromise solutions is proposed, which consists of the following:

- Alternatives $A^{(1)}$ and $A^{(2)}$ if only the second condition is not satisfied, or

- Alternatives $A^{(1)}$ and $A^{(2)}, \ldots, A^{(M)}$ if the first condition is not satisfied; $A^{(M)}$ is determined by the relation for maximum $M$ (the positions of these alternatives are 'in closeness').

$Q\left(A^{(M)}\right)-Q\left(A^{(1)}\right)<\frac{1}{m-1}$

The WASPAS method

The WASPAS method is a combination of two approaches, i.e. weighted sum model (WSM) and weighted product model (WPM). The alternatives are ranked according to the value of criterion $Q_{i}$ which is perfected in [26] as follows:

$Q_{i}=\lambda \cdot \sum_{j=1}^{n} \bar{x}_{i j} \cdot w_{j}+(1-\lambda) \cdot \prod_{j=1}^{n}\left(\bar{x}_{i j}\right)^{w_{j}}$

where: $\lambda$ is a parameter.

The following condition is valid:

$0 \leq \lambda \leq 1$

where: $\bar{x}_{i j}$ is the normalized value of $x_{i j} ; n$ is the number of criteria, $m$ is the number of alternatives; $\lambda$ is a parameter.

For beneficial criteria,

$\bar{x}_{i j}=\frac{x_{i j}}{\max _{j} x_{i j}}, \quad i=1, \ldots, n ; j=1, \ldots, m$

For non-beneficial criteria

$\bar{x}_{i j}=\frac{\min _{j} x_{i j}}{x_{i j}}, i=1, \ldots, n ; j=1, \ldots, m$

The alternative with minimal value of the criterion is the best. 
The PROMETHEE method for ranking variant schemes

The PROMETHEE method uses a preference function which characterises the difference for a criterion between the evaluations obtained from two possible decisions into a preference degree ranging from 0 to 1. The method applies six basic preference functions - usual criterion; quasi criterion; criterion with linear preference; level criterion; criterion with linear preference and indifference area; Gaussian criterion. The PROMETHEE method consists of the following main steps, [27]:

Step 1: Computing for each pair of possible decisions and for each criterion, the value of the preference degree.

Step 2: Determination for each pair of possible decisions of the global preference index.

Step 3: Ranking of the possible decisions and computing of the positive and negative outranking flows. The positive outranking flow expresses how much each alternative outranks all the others. The negative outranking flow expresses how much each alternative is outranked by all the others.

Step 4: Determination of the net outranking flows $\phi\left(a_{j}\right)$ of $a_{j}$ in the alternatives set $m$ of a possible decision as a difference between positive and negative outranking flows. The highest value of the net outranking flow shows the best decision. For the net outranking flow, the following conditions are valid:

$$
\varphi\left(a_{j}\right) \in[-1 ; 1], \sum_{j=1}^{m} \varphi\left(a_{j}\right)=0
$$

\section{RESULTS AND DISCUSSION}

\subsection{Determination of the weights of criteria}

The methodology is used for ranking 12 railway markets in the Balkan region. Table 2 presents the decision matrix with values of criteria defined in Step 1 for all investigated countries.

The criteria: availability of Ro-La service $\left(C_{5}\right)$, maximum train technical speed $\left(C_{6}\right)$, ERTMS Levels $\left(C_{7}\right)$, and availability of car shuttle service $\left(C_{20}\right)$ are set with values 0,1 or 2, according to the nature of investigated indicator. The ERTMS Level is determined according to [28].

The parameters and the results of the weights obtained by means of the Shannon Entropy method are presented in Table 3. It can be seen that the most important criteria according to this method are the availability of Ro-La service $\left(C_{5}=0.11\right)$, and the maximum train technical speed $\left(C_{6}=0.11\right)$.

In the study, the assessments obtained by means of the SWARA method have been given by five experts. The experts' selection has been conducted according to the following criteria: experience in railway transport of more than 20 years; occupied position in the Ministry of Transport, Information Technology and Communications or Railway operator; participation in the international projects related to railway transport; scientific and research experience in the field of railway transport in academia. They are evaluated independently of each other with the comparative importance $S_{i}$. The final weights are determined as average values of experts' assessment. Table 4 shows the values of comparative importance and weights for each expert. The end of the table shows the average values of weights obtained by the SWARA method. It can be seen that the most important criteria are: availability of high-speed service $\left(C_{6}=0.14\right)$, level of ERTMS $\left(C_{7}=0.12\right)$ and the number of train-kilometres per year $\left(C_{8}=0.13\right)$.

Table 5 presents the Spearman Rank Correlation coefficients between expert evaluations. The last row in the table shows the values of Spearman Rank Correlation coefficients between the average value of weights and each of the expert's assessment. It can be concluded that there is a strong correlation between the experts' evaluations and their average score.

The results obtained by both methods, Shannon Entropy and SWARA indicate that the criterion availability of high-speed service $\left(C_{6}\right)$ is of the highest value.

The final weights of the criteria are determined by Formula 13 by examining the influence of the change of parameter $\varepsilon$ on both applied methods. Figure 2 shows a comparison of the weights of the criteria according to parameter $\varepsilon$.

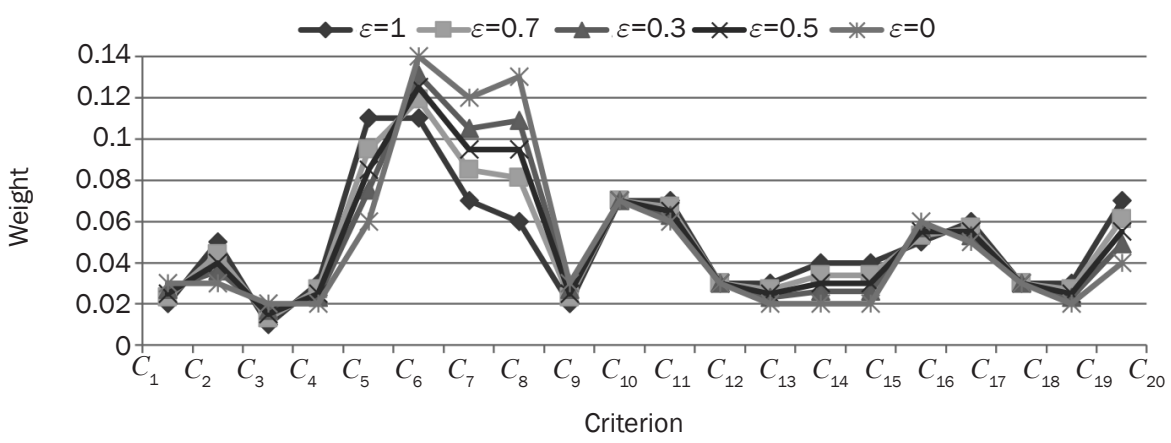

Figure 2 - Comparison of the weights of the criteria according to parameter $\varepsilon$ 


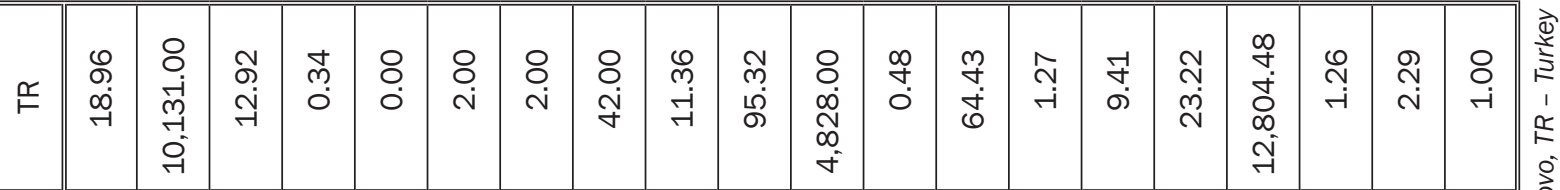

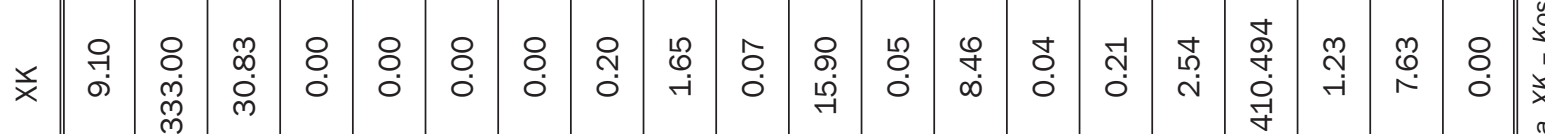

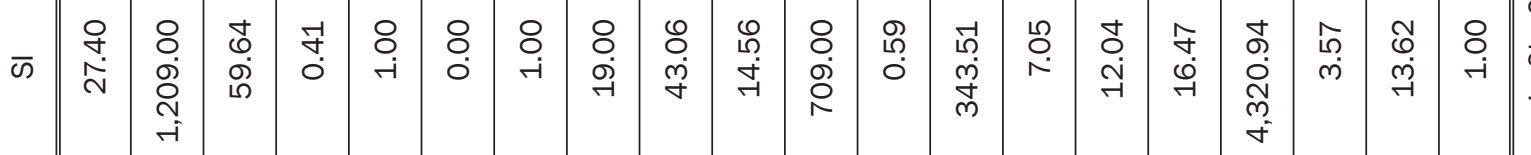

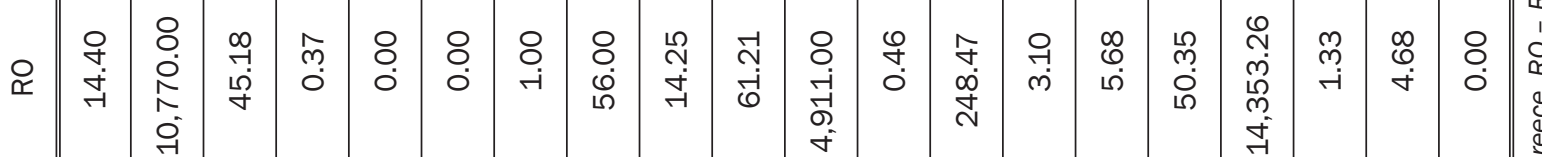

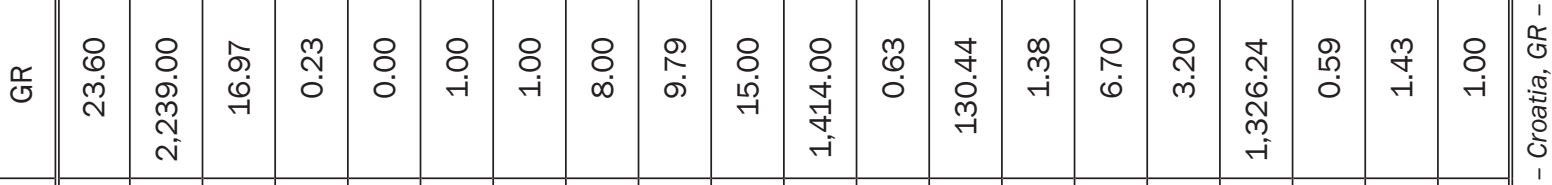

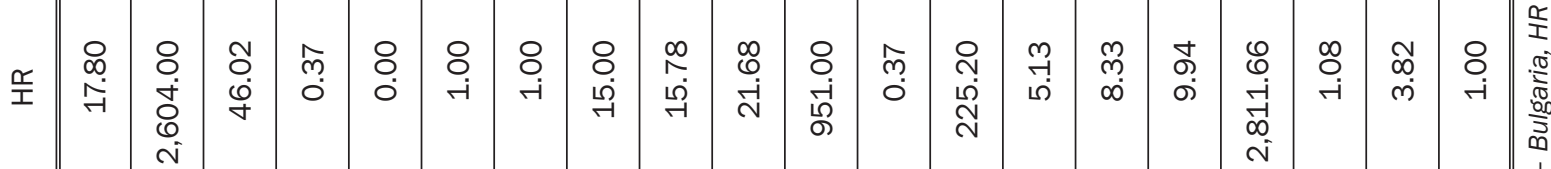

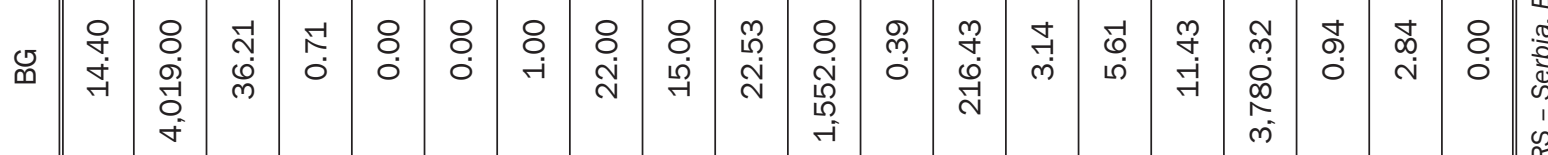

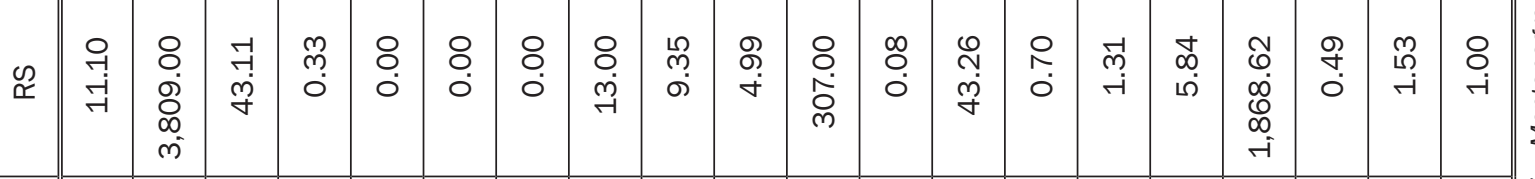

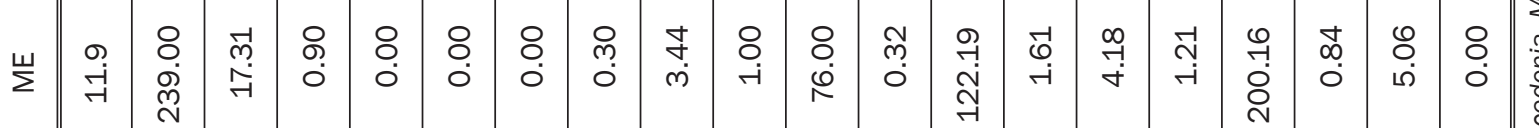

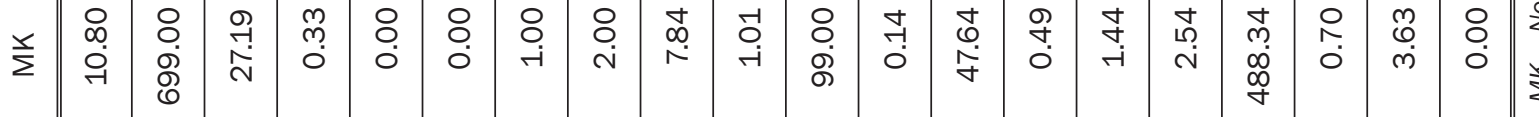

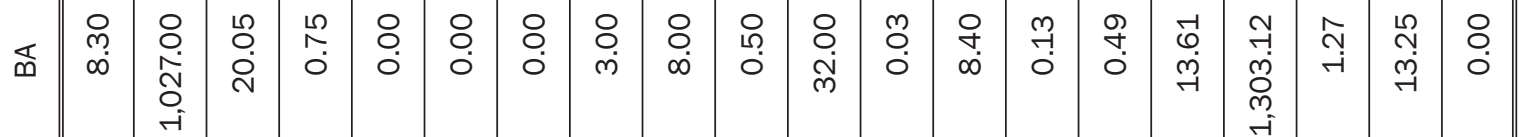

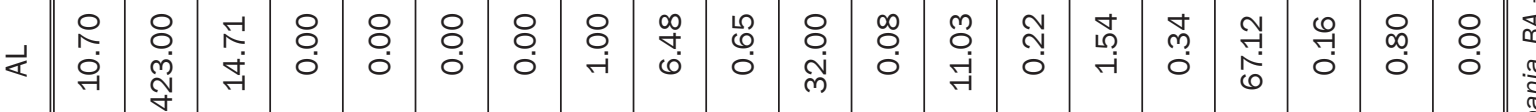

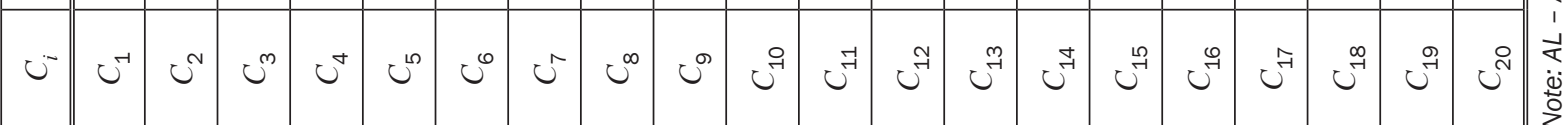


Table 3 - Parameters of Shannon Entropy method

\begin{tabular}{||l|l|l|l||}
\hline$C_{i}$ & $E_{i}$ & $D_{i}$ & $w_{i}^{E}$ \\
\hline \hline$C_{1}$ & 0.88 & 0.12 & 0.02 \\
\hline$C_{2}$ & 0.64 & 0.36 & 0.05 \\
\hline$C_{3}$ & 0.91 & 0.09 & 0.01 \\
\hline$C_{4}$ & 0.81 & 0.19 & 0.03 \\
\hline$C_{5}$ & 0.29 & 0.71 & 0.11 \\
\hline$C_{6}$ & 0.28 & 0.72 & 0.11 \\
\hline$C_{7}$ & 0.52 & 0.44 & 0.07 \\
\hline$C_{8}$ & 0.62 & 0.38 & 0.06 \\
\hline$C_{9}$ & 0.81 & 0.19 & 0.03 \\
\hline$C_{10}$ & 0.52 & 0.48 & 0.07 \\
\hline$C_{11}$ & 0.53 & 0.47 & 0.07 \\
\hline$C_{12}$ & 0.78 & 0.22 & 0.03 \\
\hline$C_{13}$ & 0.78 & 0.22 & 0.02 \\
\hline$C_{14}$ & 0.73 & 0.27 & 0.04 \\
\hline$C_{15}$ & 0.74 & 0.26 & 0.04 \\
\hline$C_{16}$ & 0.67 & 0.33 & 0.05 \\
\hline$C_{17}$ & 0.59 & 0.41 & 0.06 \\
\hline$C_{18}$ & 0.80 & 0.20 & 0.03 \\
\hline$C_{19}$ & 0.83 & 0.17 & 0.03 \\
\hline$C_{20}$ & 0.52 & 0.48 & 0.07 \\
\hline
\end{tabular}

Value $\varepsilon=1$ presents the results of the Shannon Entropy method, and value $\varepsilon=0$ shows the results of the SWARA method.

Most important are the criteria of maximum train technical speed $\left(C_{6}\right)$, level of ERTMS $\left(C_{7}\right)$ and the number of train-kilometres per year $\left(C_{8}\right)$.

Table 6 presents the results of the determination of the weights of the main groups of criteria according to Formulas 15 and 16 . The weights of the mean criteria are shown in the last column of the table. It can be seen that the infrastructural group has the main impact (0.38); and the results of weights for the technological and social group are close.

Table 5 - Spearman Rank Correlation coefficient

\begin{tabular}{|c|c|c|c|c|c||}
\hline \hline Expert & 1 & 2 & 3 & 4 & 5 \\
\hline \hline 1 & - & 1.00 & 0.66 & 0.67 & 0.58 \\
\hline 2 & 1.00 & - & 0.75 & 0.81 & 0.72 \\
\hline 3 & 0.66 & 0.75 & - & 0.86 & 0.93 \\
\hline 4 & 0.67 & 0.81 & 0.86 & - & 0.91 \\
\hline 5 & 0.58 & 0.72 & 0.93 & 0.91 & - \\
\hline Average & 0.90 & 0.96 & 0.81 & 0.84 & 0.80 \\
\hline
\end{tabular}

Table 4 - Experts' assessment $S_{i}$, values of weights $w_{i}^{S}$ by the SWARA method

\begin{tabular}{|c|c|c|c|c|c|c|c|c|c|c|c|c|c|c|c|c|}
\hline \multicolumn{3}{|c|}{ Expert 1} & \multicolumn{3}{|c|}{ Expert 2} & \multicolumn{3}{|c|}{ Expert 3} & \multicolumn{3}{|c|}{ Expert 4} & \multicolumn{3}{|c|}{ Expert 5} & \multicolumn{2}{|c|}{ Average } \\
\hline$C_{i}$ & $S_{i}$ & $w_{i}^{S}$ & $C_{i}$ & $S_{i}$ & $w_{i}^{S}$ & $C_{i}$ & $S_{i}$ & $w_{i}^{S}$ & $C_{i}$ & $S_{i}$ & $w_{i}^{S}$ & $C_{i}$ & $S_{i}$ & $w_{i}^{S}$ & $C_{i}$ & $w_{i}^{S}$ \\
\hline$\overline{c C_{6}}$ & & 0.13 & $\overline{C C_{6}}$ & & 017 & $\overline{C_{6}}$ & & 0.23 & $\overline{C_{8}}$ & & 0.24 & $C_{10}$ & & 0.18 & $\overline{C_{1}}$ & 0.03 \\
\hline$C_{7}$ & 22 & 0.11 & $C_{7}$ & 0.33 & 0.13 & $C_{7}$ & 0.40 &. $\pm t$ & $C_{7}$ & 0.38 & 0.17 & $C_{16}$ & 0.30 & 0.14 & $C_{2}$ & 0.03 \\
\hline$C_{8}$ & 20 & 0.09 & $C_{1}$ & 0.3 & 0.09 & $C_{8}$ & 0.30 & 0.13 & $C_{6}$ & 0.40 & 0.13 & $C_{8}$ & 0.32 & 0.11 & $C_{3}$ & 0.02 \\
\hline$C_{5}$ & 0.18 & 0.08 & $C_{8}$ & 0.2 & 0.08 & $C_{11}$ & 0.35 & 0.09 & $C_{5}$ & 0.35 & 0.09 & $C_{11}$ & 0.30 & 0.08 & $C_{4}$ & 0.02 \\
\hline$C_{11}$ & .16 & 0.07 & $C_{2}$ & 0.2 & 0.07 & $C_{17}$ & 0.32 & 0.07 & $C_{20}$ & 0.32 & 0.07 & $C_{17}$ & 0.25 & 0.07 & $C_{5}$ & 0.06 \\
\hline$C_{17}$ & 0.16 & 0.06 & $C_{9}$ & 0.15 & 0.06 & $C_{10}$ & 030 & 0.05 & $C_{10}$ & 0.30 & 0.06 & $C_{7}$ & 0.25 & 0.05 & $C_{6}$ & 0.14 \\
\hline$C_{20}$ & 0.12 & 0.05 & $C_{12}$ & 0.15 & 0.05 & $C_{16}$ & 0.30 & 0.04 & $C_{16}$ & 0.30 & 0.04 & $C_{6}$ & 0.20 & 0.04 & $C_{7}$ & 0.12 \\
\hline$C_{2}$ & 0.10 & 0.05 & $C_{18}$ & 0.15 & 0.04 & $C_{5}$ & 0.25 & 0.04 & $C_{11}$ & 0.25 & 0.03 & $C_{5}$ & 0.20 & 0.04 & $C_{8}$ & 0.13 \\
\hline$C_{4}$ & 0.09 & 0.04 & $C_{4}$ & 0.12 & 0.04 & $C_{20}$ & 0.25 & 0.03 & $C_{17}$ & 0.25 & 0.03 & $C_{20}$ & 0.18 & 0.04 & $C_{9}$ & 0.03 \\
\hline$C_{3}$ & 0.09 & 0.04 & $C_{5}$ & 0.10 & 0.04 & $C_{9}$ & 0.20 & 0.02 & $C_{9}$ & 0.20 & 0.02 & $C_{9}$ & 0.15 & 0.03 & $C_{10}$ & 0.07 \\
\hline$C_{10}$ & 0.08 & 0.04 & $C_{3}$ & 0.10 & 0.03 & $C_{12}$ & 0.18 & 0.02 & $C_{12}$ & 0.18 & 0.02 & $C_{12}$ & 0.12 & 0.03 & $C_{11}$ & 0.06 \\
\hline$C_{16}$ & 0.08 & 0.03 & $C_{16}$ & 0.10 & 0.03 & $C_{18}$ & 0.18 & 0.02 & $C_{18}$ & 0.18 & 0.02 & $C_{18}$ & 0.12 & 0.03 & $C_{12}$ & 0.03 \\
\hline$C_{9}$ & 0.08 & 0.03 & $C_{15}$ & 0.10 & 0.03 & $C_{15}$ & 0.15 & 0.02 & $C_{3}$ & 0.15 & 0.01 & $C_{3}$ & 0.10 & 0.02 & $C_{13}$ & 0.02 \\
\hline$C_{12}$ & 0.07 & 0.03 & $C_{19}$ & 0.10 & 0.02 & $C_{19}$ & 0.12 & 0.01 & $C_{15}$ & 0.12 & 0.01 & $C_{15}$ & 0.09 & 0.02 & $C_{14}$ & 0.02 \\
\hline$C_{18}$ & 0.07 & 0.03 & $C_{11}$ & 0.08 & 0.02 & $C_{13}$ & 0.11 & 0.01 & $C_{19}$ & 0.11 & 0.01 & $C_{19}$ & 0.09 & 0.02 & $C_{15}$ & 0.02 \\
\hline$C_{15}$ & 0.06 & 0.03 & $C_{17}$ & 0.08 & 0.02 & $C_{14}$ & 0.10 & 0.01 & $C_{13}$ & 0.10 & 0.01 & $C_{13}$ & 0.06 & 0.02 & $C_{16}$ & 0.06 \\
\hline$C_{19}$ & 0.05 & 0.03 & $C_{13}$ & 0.08 & 0.02 & $C_{3}$ & 0.09 & 0.01 & $C_{14}$ & 0.09 & 0.01 & $C_{14}$ & 0.06 & 0.02 & $C_{17}$ & 0.05 \\
\hline$C_{13}$ & 0.04 & 0.02 & $C_{20}$ & 0.05 & 0.02 & $C_{2}$ & 0.05 & 0.01 & $C_{1}$ & 0.05 & 0.01 & $C_{2}$ & 0.05 & 0.02 & $C_{18}$ & 0.03 \\
\hline$C_{14}$ & 0.03 & 0.02 & $C_{10}$ & 0.05 & 0.02 & $C_{4}$ & 0.04 & 0.01 & $C_{2}$ & 0.04 & 0.01 & $C_{1}$ & 0.05 & 0.02 & $C_{19}$ & 0.02 \\
\hline$C_{1}$ & 0.03 & 0.02 & $C_{14}$ & 0.05 & 0.02 & $C_{1}$ & 0.03 & 0.01 & $C_{4}$ & 0.03 & 0.01 & $C_{4}$ & 0.03 & 0.02 & $C_{20}$ & 0.04 \\
\hline
\end{tabular}


Table 6 - Weights of criteria

\begin{tabular}{|c|c|c|c|c|c|c|c|}
\hline Main group & Criterion & $w_{i}^{E}$ & $w_{i}^{S}$ & $w_{i}$ & $K$ & $w_{g}$ & $\bar{w}_{g}$ \\
\hline Economic & $C_{1}$ & 0.02 & 0.03 & 0.03 & 1 & 0.03 & 0.16 \\
\hline \multirow{7}{*}{ Infrastructural } & $C_{2}$ & 0.05 & 0.03 & 0.04 & \multirow{7}{*}{7} & \multirow{7}{*}{0.07} & \multirow{7}{*}{0.38} \\
\hline & $C_{3}$ & 0.01 & 0.02 & 0.02 & & & \\
\hline & $C_{4}$ & 0.03 & 0.02 & 0.03 & & & \\
\hline & $C_{5}$ & 0.11 & 0.06 & 0.09 & & & \\
\hline & $C_{6}$ & 0.11 & 0.14 & 0.13 & & & \\
\hline & $C_{7}$ & 0.07 & 0.12 & 0.10 & & & \\
\hline & $C_{8}$ & 0.06 & 0.13 & 0.09 & & & \\
\hline \multirow{11}{*}{ Technological } & $C_{9}$ & 0.03 & 0.03 & 0.03 & \multirow{11}{*}{11} & \multirow{11}{*}{0.04} & \multirow{11}{*}{0.20} \\
\hline & $C_{10}$ & 0.07 & 0.07 & 0.07 & & & \\
\hline & $C_{11}$ & 0.07 & 0.06 & 0.06 & & & \\
\hline & $C_{12}$ & 0.03 & 0.03 & 0.03 & & & \\
\hline & $C_{13}$ & 0.02 & 0.02 & 0.02 & & & \\
\hline & $C_{14}$ & 0.04 & 0.02 & 0.03 & & & \\
\hline & $C_{15}$ & 0.04 & 0.02 & 0.03 & & & \\
\hline & $C_{16}$ & 0.05 & 0.06 & 0.05 & & & \\
\hline & $C_{17}$ & 0.06 & 0.05 & 0.05 & & & \\
\hline & $C_{18}$ & 0.03 & 0.03 & 0.03 & & & \\
\hline & $C_{19}$ & 0.03 & 0.02 & 0.02 & & & \\
\hline Social & $C_{20}$ & 0.07 & 0.04 & 0.05 & 1 & 0.05 & 0.26 \\
\hline
\end{tabular}

\subsection{Ranking of the countries}

The countries in the Balkan region have been ranked by three different methods according to their nature. This approach makes it possible to verify the results.

Table 7 presents the results of index $Q_{j}$ for six different variants of weight of the decision-making strategy $v$ by the VIKOR method. The rank of the country is presented for each variant in Figure 3. It can be seen that for all the variants Turkey is in the first position. Slovenia is ranking second for the first variant of the parameter. Romania and Slovenia have close values for all variants. Croatia modifies her position when parameter $v$ is changed. For $v=0$ nine countries are in the second position.

The values given in Table 7 show that both conditions for stability of optimal results are satisfied. Turkey has rank 1 , for both criteria $S_{j}$ and $R_{j}$, and for criterion $Q_{j}$ at all values of parameter $v$. Croatia has rank 2 at five variants of values of parameter $v$. The right side of Condition 25 is value $0.09(m=12)$. The difference between the values of criterion $Q_{j}$ for the countries in the first and second position for most of the changes of parameter $v$ is greater than 0.09 , indicating that the condition in Formula 25 is met.
The results of criterion $Q_{i}$, Formula 26 when changing parameter $\lambda$ of the second applied method WASPAS are shown in Table 8. When $\lambda=1$, it corresponds to the WSM method; when $\lambda=0$, it corresponds to the WPM method. The results are similar to those of the VIKOR method. Small deviations occur in the ranking of Croatia and Greece. Romania and Slovenia have close values for all variants of parameter $\lambda$.

The research with the VIKOR and WASPAS method was performed using Excel. The third method - PROMETHEE is applied by using Visual PROMETHEE software. Figure 3 presents the results.

The first part of the figure shows the prioritization according to the net outranking flows; the second part shows the weights of the criteria determined a $s$ average value by both methods - Shannon Entropy and SWARA, $(\varepsilon=0.5)$. Turkey is in the first position. Slovenia is ranked second. The results for Croatia and Romania are close. It can be seen that the results are the same as those of the VIKOR and WASPAS method.

The stability intervals of changing the weights of the criteria in which the optimal solution is retained are shown in Table 9. The stability intervals of weights include the limits of change of parameter $\varepsilon$ by Formula 13 on both applied methods, Shannon Entropy and SWARA. 
Table 7 - Index value $Q_{j}$ and ranking by the VIKOR method

\begin{tabular}{||c|c|c|c|c|c|c|c|c|c|c|c|c||}
\hline$Q_{j}$ & $\mathrm{AL}$ & $\mathrm{BA}$ & $\mathrm{MK}$ & $\mathrm{ME}$ & $\mathrm{RS}$ & $\mathrm{BG}$ & $\mathrm{HR}$ & $\mathrm{GR}$ & $\mathrm{RO}$ & $\mathrm{SI}$ & $\mathrm{XK}$ & $\mathrm{TR}$ \\
\hline \hline$v=1$ & 1.000 & 0.893 & 0.863 & 0.881 & 0.798 & 0.601 & 0.447 & 0.535 & 0.254 & 0.235 & 0.974 & 0.000 \\
\hline Rank & 12 & 10 & 8 & 9 & 7 & 6 & 4 & 5 & 3 & 2 & 11 & 1 \\
\hline$v=0.7$ & 1.000 & 0.925 & 0.904 & 0.917 & 0.858 & 0.720 & 0.313 & 0.374 & 0.478 & 0.464 & 0.982 & 0.000 \\
\hline Rank & 12 & 10 & 8 & 9 & 7 & 6 & 2 & 3 & 5 & 4 & 11 & 1 \\
\hline$v=0.5$ & 1.000 & 0.947 & 0.931 & 0.941 & 0.899 & 0.800 & 0.224 & 0.267 & 0.627 & 0.617 & 0.987 & 0.000 \\
\hline Rank & 12 & 10 & 8 & 9 & 7 & 6 & 2 & 3 & 5 & 4 & 11 & 1 \\
\hline$v=0.3$ & 1.000 & 0.968 & 0.959 & 0.964 & 0.939 & 0.880 & 0.134 & 0.160 & 0.776 & 0.770 & 0.992 & 0.000 \\
\hline Rank & 12 & 10 & 8 & 9 & 7 & 6 & 2 & 3 & 5 & 4 & 11 & 1 \\
\hline$v=0.1$ & 1.000 & 0.989 & 0.986 & 0.988 & 0.980 & 0.960 & 0.045 & 0.053 & 0.925 & 0.923 & 0.997 & 0.000 \\
\hline Rank & 12 & 10 & 8 & 9 & 7 & 6 & 2 & 3 & 5 & 4 & 11 & 1 \\
\hline$v=0$ & 1.000 & 1.000 & 1.000 & 1.000 & 1.000 & 1.000 & 0.000 & 0.000 & 1.000 & 1.000 & 1.000 & 0.000 \\
\hline Rank & 2 & 2 & 2 & 2 & 2 & 2 & 1 & 1 & 2 & 2 & 2 & 1 \\
\hline
\end{tabular}

Table 8 - Values of criterion $Q_{i}$ according to parameter $\lambda$ by the WASPAS Method

\begin{tabular}{||c|c|c|c|c|c|c|c|c|c|c|c|c||}
\hline Country & AL & BA & MK & ME & RS & BG & HR & GR & RO & SI & XK & TR \\
\hline \hline$\lambda=1$ & 0.036 & 0.106 & 0.126 & 0.113 & 0.167 & 0.296 & 0.395 & 0.337 & 0.524 & 0.528 & 0.052 & 0.695 \\
\hline Rank & 12 & 10 & 8 & 9 & 7 & 6 & 4 & 5 & 3 & 2 & 11 & 1 \\
\hline$\lambda=0.7$ & 0.025 & 0.074 & 0.088 & 0.079 & 0.117 & 0.207 & 0.276 & 0.236 & 0.367 & 0.369 & 0.036 & 0.486 \\
\hline Rank & 12 & 10 & 8 & 9 & 7 & 6 & 4 & 5 & 3 & 2 & 11 & 1 \\
\hline$\lambda=0.5$ & 0.018 & 0.053 & 0.063 & 0.056 & 0.084 & 0.148 & 0.197 & 0.169 & 0.262 & 0.264 & 0.026 & 0.347 \\
\hline Rank & 12 & 10 & 8 & 9 & 7 & 6 & 4 & 5 & 3 & 2 & 11 & 1 \\
\hline$\lambda=0.3$ & 0.011 & 0.032 & 0.038 & 0.034 & 0.050 & 0.089 & 0.118 & 0.101 & 0.157 & 0.158 & 0.016 & 0.208 \\
\hline Rank & 12 & 10 & 8 & 9 & 7 & 6 & 4 & 5 & 3 & 2 & 11 & 1 \\
\hline$\lambda=0.1$ & 0.004 & 0.011 & 0.013 & 0.011 & 0.017 & 0.030 & 0.039 & 0.034 & 0.052 & 0.053 & 0.005 & 0.069 \\
\hline Rank & 12 & 10 & 8 & 9 & 7 & 6 & 4 & 5 & 3 & 2 & 11 & 1 \\
\hline$\lambda=0$ & 0.000 & 0.000 & 0.000 & 0.000 & 0.000 & 0.000 & 0.000 & 0.000 & 0.000 & 0.000 & 0.000 & 0.000 \\
\hline Rank & 1 & 1 & 1 & 1 & 1 & 1 & 1 & 1 & 1 & 1 & 1 & 1 \\
\hline
\end{tabular}
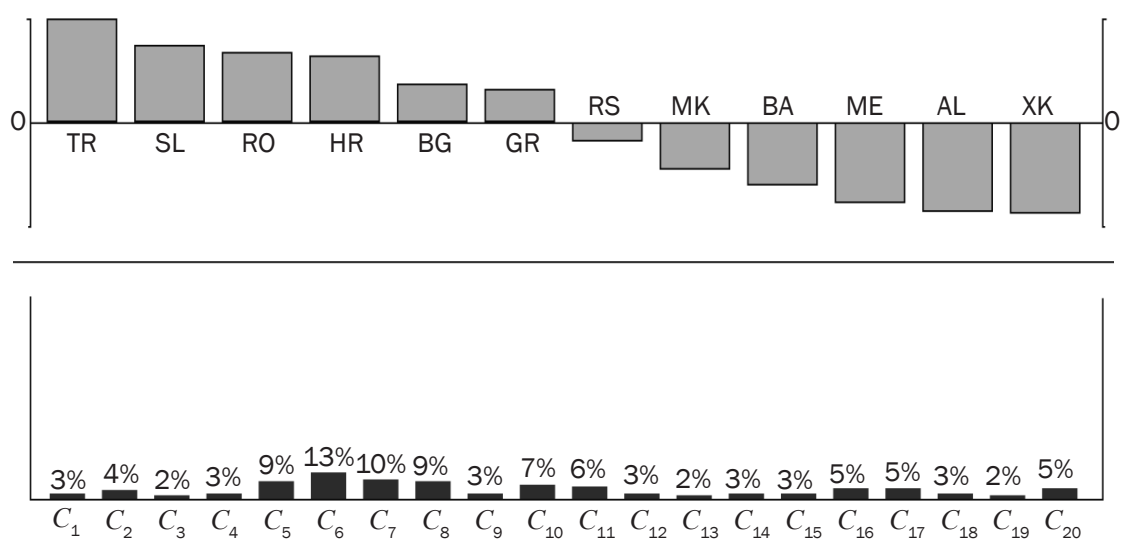

Figure 3 - Ranking by Visual PROMETHEE software

Table 9 - Stability intervals of the weights of criteria

\begin{tabular}{||l|c|c|c|c|c|c|c|c|c|c||}
\hline \hline$C_{i}$ & $C_{1}$ & $C_{2}$ & $C_{3}$ & $C_{4}$ & $C_{5}$ & $C_{6}$ & $C_{7}$ & $C_{8}$ & $C_{9}$ & $C_{10}$ \\
\hline From & 0 & 0 & 0 & 0 & 0 & 0.02 & 0 & 0 & 0 & 0 \\
\hline To & 0.26 & 0.52 & 0.08 & 1 & 0.19 & 1 & 1 & 0.54 & 0.18 & 1 \\
\hline \hline$C_{i}$ & $C_{11}$ & $C_{12}$ & $C_{13}$ & $C_{14}$ & $C_{15}$ & $C_{16}$ & $C_{17}$ & $C_{18}$ & $C_{19}$ & $C_{20}$ \\
\hline From & 0 & 0 & 0 & 0 & 0 & 0 & 0 & 0 & 0 & 0 \\
\hline To & 0.53 & 1 & 0.13 & 0.12 & 0.36 & 0.52 & 0.52 & 0.14 & 1 & 1 \\
\hline \hline
\end{tabular}


Table 10 - Comparison with [9-11]

\begin{tabular}{|c|c|c|c|c|c|c|}
\hline \multirow[b]{2}{*}{ Country } & \multicolumn{3}{|c|}{ Rank by methodology } & \multirow{2}{*}{$\begin{array}{c}\text { Rank by logistic } \\
\text { performance } \\
\text { index (LPI), [11] }\end{array}$} & \multirow{2}{*}{$\begin{array}{c}\text { Rank by } \\
\text { European } \\
\text { performance } \\
\text { index (EPI), [9] }\end{array}$} & \multirow{2}{*}{$\begin{array}{c}\text { Efficiency } \\
\text { score, } \\
\%[10]\end{array}$} \\
\hline & $\begin{array}{l}\text { WASPAS } \\
(\lambda=0.5)\end{array}$ & $\begin{array}{l}\text { VIKOR } \\
(v=0.5)\end{array}$ & PROMETHEE & & & \\
\hline Turkey & 1 & 1 & 1 & 37 & - & - \\
\hline Slovenia & 2 & 2 & 2 & 39 & 18 & 73.6 \\
\hline Romania & 3 & 3 & 3 & 44 & 24 & - \\
\hline Croatia & 4 & 4 & 4 & 48 & - & - \\
\hline Greece & 5 & 5 & 6 & 58 & - & 70.2 \\
\hline Bulgaria & 6 & 6 & 5 & 50 & 25 & - \\
\hline Serbia & 7 & 7 & 7 & 67 & - & - \\
\hline North Macedonia & 8 & 8 & 8 & 98 & - & - \\
\hline Montenegro & 9 & 9 & 10 & 94 & - & - \\
\hline Bosnia-Herzegovina & 10 & 10 & 9 & 78 & - & - \\
\hline Kosovo & 11 & 11 & 12 & 99 & - & - \\
\hline Albania & 12 & 12 & 11 & - & - & - \\
\hline
\end{tabular}

\subsection{Verification of the results}

The results have been verified by two approaches. The first approach is based on the comparison of the results by applying three multi-criteria methods, and the second one uses the results of other studies as the basis for comparison.

Table 10 presents the results of the ranking of the Balkan countries by the three allied methods. The values of the parameters for the VIKOR and WASPAS methods in the figure are $v=\lambda=0.5$. The ranking of the Balkan countries by the VIKOR and WASPAS methods is similar. There are some differences in the results given by the PROMETHEE method in terms of ranking of Bulgaria and Greece; Bosnia-Herzegovina, Albania and Kosovo that have exchanged their positions.

Table 10 presents also a comparison of the results of the study and research given in $[9,10,11]$. The World Bank ranked 167 countries from all over the world by LPI, and 11 countries are from the Balkan peninsula, [11]. It can be seen that the position of the countries studied using this methodology and [11] are similar. The sixth column in Table 10 shows the position of three Balkan countries - Slovenia, Romania and Bulgaria according to [9], where 25 European railways are studied by the European Performance Index (EPI). The results show that Slovenia is ahead in the ranking as compared to Romania and Croatia. The last column of Table 10 gives the results of the efficiency score of railway transport for Slovenia and Greece which have been included in the research of 22 European railways given in [10]. The position of Slovenia is before Greece according to the efficiency score, which is similar to the ranking by our methodology.

\section{CONCLUSION}

The study produces the ranking of twelve different railway transport markets in the Balkan regions according to their railway transport development. Twenty quantitative and qualitative criteria have been defined to assess the level of railway transport. The criteria have been separated into four groups - economic, infrastructural, technological and social. A combination of both objective and subjective approaches has been applied to determine the weights of criteria by applying the Shannon Entropy method and the SWARA method. In this way it is possible to take into account both the information of the data and the opinion of the experts. The influence of each of both applied methods has been studied. The Spearman Rank correlation coefficient is applied to determine the consistency of the experts' assessment by the SWARA method. A strong correlation between the experts' evaluation was found. The study showed that the criteria: maximum train technical speed (13\%), ERTMS Level (10\%), number of train-kilometres per year (9\%) and Ro-La intermodal service (9\%) were of major importance for evaluating the railway development. It was found that the infrastructural group criteria had the main impact of assessment on the evaluation of railway transport (0.38); the results of weights for technological and social group are close. Three multi-criteria methods have been applied to evaluate the Balkan countries by the defined criteria. The study produces a ranking of the Balkan countries using the proposed methodology. The research has established that the prioritization given by VIKOR, WASPAS and PROMETHEE methods is similar. The conducted study demonstrated that the Balkan region with most highly developed railway transport are Turkey, Slovenia, Romania and Croatia.

The proposed methodology could help railway companies to compare the level of development of railway transport, and to make decisions about the way of extending and improving the railway services. In the future scientific studies, the plan is to extend the scope of the countries surveyed to other regions, as well as to explore separately the rail passenger and freight transport. 


\section{ACKNOWLEDGEMENT}

This research has been supported by contract №KП-06-H27/12 of 11.12.2018 "Modeling and elaboration of complex system for selection of transport technology in transport network" funded by the $\mathrm{Na}$ tional Science Fund of the Ministry of Education and Science of Bulgaria.

\section{СВЕТАА СТОИЛОВА, АОЦ. АТН}

E-mail: stoilova@tu-sofia.bg

Технически Университет-София, Факултет по транспорт

бул. Климент ОхриАски 8, София 1000, България

\section{МНОГОКРИТЕРИАЛЕН ПОАХОА ЗА ОЦЕНКА НА ЖЕАЕЗОПЪТНИЯ ТРАНСПОРТ В БАЛКАНСКИЯ РЕГИОН}

\section{РЕЗЮМЕ}

Балканският регион има важно геостратегическо положение за пътническия и товарен транспорт между Европа и Азия. Тази статия изследва развитието на железопътния транспорт в 12 различни железопътни транспортни пазари в региона на Балканите. Методиката се основава на многокритериална оценка на нивото на развитие нажелезопътниятранспорт. Подходът, представен в този статия, можеда помогне на железопътните компании Аа вземат решения относно железопътните транспортни услуги. Методиката включва три стьпки. В първата стьпка са дефинирани количествените и качествени критерии за оценка на социалното, икономическото, инфраструктурното и технологичното въздействие върху степента на развитие на железопътния транспорт. Във втората стьпка се определят теглата на критериите, чрез използването както на обективни, така и на субективни подходи, като се прилагат методът на ентропията на Шанън и стъпковият начин за анализ на съотношението на теглото (SWARA). Третата стьпка представя к^асация на Аържавите чрез прилагане на три многокритериални метода - Оптимизация на критерии и компромисно решение (VIKOR), Претеглена обобщена сума за оценка на резултата (WASPAS) и МетоА за организация на преАпочитанията за подобряване на оценката (PROMETHEE), които са с различни подходи. Резултатите показват, че критериите: максимална експлоатационна скорост на влака (13\%), ниво на ERTMS (10\%), брой влаккилометри годишно (9\%) и Ro-La интермодални превози (9\%) имат голямо значение за ранкирането. Установено е, че Турция, Хърватия, Словения и Румъния са с най-развитите железопътни превози в Балканския регион.

\section{КАЮчОВИ АУМИ}

железопътен транспорт; ентропия; оценяване;

\section{REFERENCES}

[1] Develioğlu K, Kantarci K. Clustering Balkan Countries Based on Competitiveness Factors: A Strategic Perspective. Journal of Economic and Social Studies. 2012;2(2): 237-244.

[2] Tsanana E, Katrakilidis C, Pantelidis P. Balkan Area and EU-15: An Empirical Investigation of Income Convergence. In: Karasavvoglou A, Polychronidou P. (eds.) Balkan and Eastern European Countries in the Midst of the Global Economic Crisis, Contributions to Economics. Berlin Heidelberg: Springer-Verlag; 2012. p. 23-33. Available from: doi:10.1007/978-3-79082873-3_2

[3] Papadaskalopoulos A, Karaganis A, Christofakis M. The spatial impact of EU Pan-European transport axes: City clusters formation in the Balkan area and developmental perspectives. Transport Policy. 2005;12: 488-499. Available from: doi:10.1016/j. tranpol.2005.02.009

[4] Begović N, Vukanović S. ERTMS deployment in the Western Balkans. Railway review. 2017;5: Article 70349. Available from: ttps://www.globalrailwayreview.com/article/70349/ertms-western-balkans

[5] Assessment of ITS deployment on TEN-T Core Network in the Western Balkans; 2016. Available from: http://www.seetoint.org/wp-content/uploads/downloads/2017/05/ITS-SEETO-2016.compressed.pdf

[6] Tomić V, Marinković Z, Janošević D. PROMETHEE method implementation with multi-criteria decisions. Facta Universitatis: Mechanical Engineering. 2011;9(2): 193-202.

[7] Develioglu K, Kantarci K. Tourism Performance of Balkan Countries: Travel and Tourism Competitiveness Pillars as Determining Factors. In: Proceedings of $1^{\text {st }}$ International Conference on Economic and Social Studies; 2013. p. 1588-1594.

[8] Despotović D, Filipović M, llić V. Infrastructure as a competitiveness factor in the western Balkan countries. Facta Universitatis: Economics and Organization. 2016; 13(1): 1-15.

[9] Duranton S, Audier A, Hazan J, Langhorn M, Gauche V. The 2017 European Railway Performance Index. The Boston Consulting Group; 2017. Available from: http://image-src.bcg.com/Images/BCG-The-2017-European-Railway-Performance-Index-Apr-2017-2_tcm9152164.pdf [Accessed $3^{\text {rd }}$ Feb 2019].

[10] Wetzel H. Productivity Growth in European Railways: Technological Progress, Efficiency Change and Scale Effects. Working Paper Series in Economics No. 101, 2008. Available from: http://www.uni-lueneburg.de/ $\mathrm{fb} 2 / \mathrm{vwl} /$ papers/wp_101_ Upload.pdf [Accessed $3^{\text {rd }}$ Feb 2019].

[11] Arvis JF, Saslavsky D, Ojala L, Shepherd B, Busch C, Raj A, Naula T. Connecting to Compete 2018 Trade Logistics in the Global Economy. Available from: https:// Ipi.worldbank.org/ [Accessed $3^{\text {rd }}$ Feb 2019].

[12] Mardan A, Zavadskas EK, Govindan K, Senin AA, Jusoh A.VIKOR Technique: A Systematic Review of the State of the Art Literature on Methodologies and Applications. Sustainability. 2016; 8(37). Available from: doi:10.3390/su8010037

[13] Behzadian M, Kazemzadeh RB, Albadvi A, Aghdasi M. PROMETHEE: A comprehensive literature review on methodologies and applications. European Journal of Operational Research. 2010;200(1): 198-215. Available from: doi:10.1016/j.ejor.2009.01.021

[14] Kosijer M, Ivić M, MarkovićM, Belošević I. Multicriteria decision-making in railway route planning and design. Građevinar. 2012;64(3): 195-205.

[15] Atanasković P, Gajić V, Dadić I, Nikoličić S: Selection 
of Forklift Unit for Warehouse Operation by Applying Multi-Criteria Analysis. Promet - Traffic\&Transportation. 2013;25(4): 379-386.

[16] Soner O, Celik E, Akyuz E. Application of AHP and VIKOR methods under interval type 216 . fuzzy environment in maritime transportation. Ocean Engineering. 2017;129(1): 107-116. Available from: doi:10.1016/j. oceaneng.2016.11.010

[17] Belošević I, Kosijer M, Ivić M, Pavlović N. Group decision making process for early stage evaluations of infrastructure projects using extended VIKOR method under fuzzy environment. European Transport Research Review. 2018;10-43. Available from: doi:10.1186/ s12544-018-0318-4

[18] Stević Z, Pamučar D, Subotić M, Antuchevičiene J, Zavadskas EK. The Location Selection for Roundabout Construction Using Rough BWM-Rough WASPAS Approach Based on a New Rough Hamy Aggregator. Sustainability. 2018;10: 2817. Available from: doi:10.3390/su10082817

[19] Chakraborty S, Zavadskas EK, Antucheviciene J. Applications of WASPAS method as a multi-criteria decision-making tool. Economic Computation and Economic Cybernetics Studies and Research. 2015; 49(1): 5-22. Available from: http://www.ecocyb.ase.ro/ nr20151/01\%20-\%20Shankar\%20CHAKRABORTY\%20 (Zavasdakas)\%20(T).pdf

[20] Srinivasa R, Kumar D. Multicriteria Analysis in Engineering and Management. Delhi: PHL Learning Private Limited; 2014.

[21] Kersuliene V, Zavadskas EK, Turskis Z. Selection of rational dispute resolution method by applying new step-wise weight assessment ratio analysis (SWARA), Journal of Business Economics and Management. 2010;11(2): 243-258.

[22] Radović D, Stević Ž. Evaluation and selection of KPI in transport using SWARA method. Transport \& Logistics: The International Journal. 2018; 8(44): 60-68.

[23] Vesković S, Stević Z, Stojić G, Vasiljević M, Milinković M. Evaluation of the railway management model by using a new integrated model DELPHI-SWARA-MABAC. Decision-making: Applications in Management and Engineering. 2018;1(2). Available from: doi:10.31181/ dmame1802034v

[24] Myers J, Well A. Research Design and Statistical Analysis. $2^{\text {nd }}$ ed. Lawrence Erlbaum; 2003.

[25] Opricovic S, Tzeng GH. Extended VIKOR method in comparison with outranking methods. European Journal of Operational Research. 2007;178(2): 514-529.

[26] Šaparauskas J, Zavadskas EK, Turskis Z. Selection of facade's alternatives of commercial and public buildings based on multiple criteria. International Journal of Strategic Property Management. 2011;15(2): 189-203.

[27] Brans JP, Mareschal B. PROMETHEE Methods. In: Multiple Criteria Decision Analysis: State of the Art Surveys. International Series in Operations Research \& Management Science, vol. 78. New York, NY: Springer; 2005. p. 163-186. Available from: doi:10.1007/0387-23081-5_5

[28] ERTMS Deployment Statistics. Available from: http:// www.ertms.net/?page_id $=55$ 